\title{
Factors Affecting the Intention to Adopt M-Learning
}

\author{
Sanduni I. Senaratne ${ }^{1}$, Samantha M. Samarasinghe ${ }^{2}$ \\ ${ }^{1}$ Faculty of Management Studies and Commerce, University of Sri Jayewardenepura, Gangodawila, Nugegoda, Sri \\ Lanka \\ ${ }^{2}$ Faculty of Management Studies and Commerce, University of Sri Jayewardenepura, Gangodawila, Nugegoda, Sri \\ Lanka \\ Correspondence: Sanduni I. Senaratne, Faculty of Management Studies and Commerce, University of Sri \\ Jayewardenepura, Gangodawila, Nugegoda, Sri Lanka.
}

Received: December 4, 2018

Accepted: January 17, 2019

Online Published: January 21, 2019

doi:10.5539/ibr.v12n2p150

URL: https://doi.org/10.5539/ibr.v12n2p150

\begin{abstract}
Over the recent years, emerging technological applications have been used for making student learning more effective and interactive. M-Learning has been one such technological initiative which has shown promising benefits in the higher education context. Even though the importance of mobile learning has been researched by many, the factors influencing mobile learning adoption intention has not been addressed sufficiently, particularly in the Sri Lankan context. Hence, the purpose of this paper was to present a conceptual model to examine the factors influencing the intention to adopt mobile learning by the students engaged in higher education. Based on a comprehensive literature review, this study extended the Technology Acceptance Model (TAM) (Davis, 1989) with mobile self-efficacy, intrinsic motivation to use mobile devices and the system quality of the m-Learning system. The model describes how the aforementioned factors influence the higher education students' intention to adopt m-Learning via survey data collected from 151 postgraduate students. The findings suggest that the model explained the factors influencing the intention to adopt $\mathrm{m}$-Learning among students in higher education. In detail, the mobile self -efficacy, system quality and intrinsic motivation significantly influenced the intention to adopt m-Learning. The results could be utilized for increasing the adoption of m-Learning practices and developing mobile applications useful for teaching and learning purposes. This study has incorporated three independent constructs in extending the TAM model; namely, system quality, mobile self-efficacy and intrinsic motivation. These were derived from the IS Success theory, Self-efficacy theory and Self-determination theory respectively. Accordingly, this study intends to address the theoretical gap in the higher education context pertaining to the adoption of mobile learning. Since Mobile Self-Efficacy and System Quality were the most significant factors that affect the perceived ease of use and perceived usefulness, these factors should be given prominence when developing mobile enabled Learning Management Systems within institutions.
\end{abstract}

Keywords: mobile learning, higher education, information and communication technology, technology acceptance model

\section{Introduction}

Recent trend in higher education indicates a tendency to seek and assimilate new tools into the educational process for enabling student learning (Lillejord Borte, Nesje \& Ruud, 2018). One of the major contributing factors is the capabilities of the new technology (Costley, 2014). Information and communication technology (ICT) plays a prominent role in enabling educational, administrative and support tasks in an extensive range (Akour, 2009). Mobile learning or m-Learning is one such technological initiative that has transformed the learning process in higher education (Klimova \& Poulova, 2016). The term m-Learning has been defined by several researchers in the past (Harris, 2001; Quinn, C., 2000; Wood, K., 2003). In this study, m-Learning is defined as, "Any sort of learning that happens when the learner is not at a fixed, predetermined location, or learning that happens when the learner takes advantage of the learning opportunities offered by mobile technologies" (O'Malley et al., 2005, p.7). The increased tendency to adopt mobile learning by higher education institutions will continue expanding their boundaries with the diffusion of numerous mobile technologies and devices. The next generation of mobile learning is expected to be pervasive and that learners will be more mobile and able to learn using multiple devices (Ally \& Prieto-Blázquez, 2014). Previous studies on m-Learning have identified five educational benefits of m-Learning: (a) portability, (b) interactivity, (c) context sensitivity, (d) 
connectivity and (e) individuality (BenMoussa, C. 2003; Churchill \& Churchill, 2008; Sharples, 2000).

Although m-Learning has many advantages, there are serious considerations regarding the readiness for the adoption of $\mathrm{m}$-Learning in higher education institutions, due to certain inherent limitations (Al-Mushasha, 2010; Ally \& Prieto-Blázquez, 2014). Kukulska-Hulme (2007) stated that the mobile learning success depends on the human factor which uses them. Although, many studies have been conducted emphasizing the importance of mobile learning, equal prominence has not been given to research on factors influencing the mobile learning adoption intention of students pursuing higher education, especially in the Sri Lankan context. Therefore, the purpose of this paper was to examine the factors influencing the intention to adopt mobile learning by the students engaged in higher education.

The findings of this study, further validated the existing models of m-Learning adoption and it also extends the existing models by adding constructs from IS success theory, self-efficacy theory and self-determination theory. Further, the model validated in this research would help administrators and learning content developers by assisting their decision making regarding the designing and administering of educational programs involving m-Learning. Particularly, it has a high potential to have an impact on formulating proper strategies in implementing successful m-Learning initiatives in their institutions.

\subsection{Literature Review}

Mobile technology has paved many ways to enhance the efficiency and effectiveness of learning by offering a learning environment that is not limited by place or time. The availability of advanced hardware and software has made it possible to enjoy new capabilities of ICT in organizing, manipulating and generating information for teaching and learning (Chen et al., 2008; Keskin \& Metcalf, 2011). Since mobile devices have become increasingly popular in universities, higher education has become an ideal venue for promoting student centered $\mathrm{m}$ - Learning.

Studies have been conducted on various applications that are being used to facilitate learning via mobile technologies in the higher education context (Lim et al., 2011; Reychav \& Wu, Hwang, Su \& Huang, 2012). There are numerous ways in which mobile learning is being applied in the higher education context within universities (Crawford, 2007). Studies have found the use of new technological tools for mobile based learning (Hao, Mengyao, Dennen, Türel \& Li, 2017; Park, 2011; Churchill \& Wang, 2014; Engin \& Donanci, 2015 and Gikas \& Grant, 2013). Mobile learning can take place both within the classroom as well as outside the classroom. Calma, Webster, Petry and Pesina (2014) examined the in class mobile learning applications in terms of student response systems. Administrative tasks such as monitoring students' progress can be done using mobile devices (Keller, 2011). Reychav, Dunaway and Kobayashi (2015) focused on informal m-Learning applications that occur outside the classroom. A number of studies have examined the innovative learning approaches that involve personalized m-Learning services (Liu, Scordino, Geurtz, Navarrete, Ko \& Lim, 2014; Wu et al. 2012). Studies associated with learner mobility have examined the usage of mobile devices in collaborative learning (Redondo et al., 2014, Kuadey, 2010). Another area of research interest has been the usage of mobile platforms for assessment and evaluation. (Bogdanović, Barać, Jovanić, Popović \& Radenković, 2014). Wang, Chen and Khan (2014) researched on the collaboration between cloud computing and mobile learning. Further, Baran (2014) studied the trends and gaps in literature pertaining to integrating mobile learning in the context of teaching. However, implementing m-Learning in higher education is still found to be challenging, due to various social, cultural and organizational concerns (Corbeil \& Valdes-Corbeil, 2007; Traxler, 2007, 2010). This raises the need for understanding perceptions toward m-Learning, which could provide the foundation for implementing m-Learning in higher education.

Several studies have highlighted the importance of identifying the students' expectations and perceptions before implementing m-Learning applications (Liu, Li, \& Carlsson, 2010; Lowenthal, 2010; Wang, Zhu \& Chen, 2009). Andersson (2008) introduced a framework which grouped the key factors affecting the success of e-Learning, namely, student, teacher, institution, support, course, technology, costs and society. Aish and Love (2013) found that performance expectancy, effort expectancy, lecturers' influence, quality of service, and personal innovativeness as significant predictors in adopting m-Learning. In some other studies, it was further validated that performance expectancy, effort expectancy and self-management of learning as significant predictors of m-Learning (Lowenthal, 2010; Wang, Wu \& Wang, 2009). Liu et al. (2010) found perceived usefulness and personal innovation as significant determinants of m-Learning. Liu et al. (2010) and Zampou, Saprikis, Markos \& Vlachopoulou, (2012) also found that perceived usefulness and personal innovation have a significant effect on the intention to adopt m-Learning. Perceptions of learners towards the educational benefits offered via m-Learning were also studies (Abdullah \& Siraj, 2010; Al-Mushasha, 2010). Nevertheless, some other studies 
have found that still there are many barriers for the adoption of m-Learning in the higher education context (Wang et al., 2009; Almaiah \& Jalil, 2014; Corbeil \& Valdes-Corbeil, 2007; Traxler, 2007, 2010). Thus, it emphasises the importance of further research in this context, in order to obtain the benefits of mobile technology in higher education.

Review of literature revealed that, Theory of Reasoned Action (TRA) (Fishbein \& Ajzen, 1975), Theory of Planned Behavior (TPB) (Ajzen, 1985, 1991), Technology Acceptance Model (TAM) (Davis, Bogozzi \& Warshaw, 1989) and Unified Theory of Acceptance and Use of Technology and Technology Acceptance (UTAUT) (Venkatesh, Morris, Davis and Davis, 2003) as the models used to investigate and explore the determinants of user behaviour towards acceptance and adoption of information technology. Amongst them TRA, TPB and TAM are highly credible theoretical models in IT acceptance and adoption literature (Wu and Lu, 2013). Although several studies have proposed different models to predict determinants of technology acceptance and adoption, the TAM has been widely adopted in predicting the determinants of technology adoption and usage in various scenarios (Lim, Lim, \& Heinrichs, 2005; Nikkheslat, Zohoori, Bekheirnia, \& Mehrafshar, 2012). Particularly, the TAM has gained a substantial empirical support in predicting technology acceptance and adoption literature (Wu \&Lu 2013). TAM can be used in predicting the behavioural intention to use a specific technology or an information system prior to the actual implementation. Hence, based on the robustness and explanatory strength (Liu \& Arnett, 2000), this study proposes a theoretical model based on the TAM.

The theoretical model proposed for this study is an extension of the Technology Acceptance Model (TAM) by Davis (1989). The TAM concentrates on the perceived ease of use and usefulness of the technology in the way how it is perceived by the user, which helps in determining future adoption. Davis (1989) defined perceived ease of use as the degree of difficulty or effort that is required to use the technology. Perceived usefulness is the extent to which an individual believes that the technology will produce better outcomes than not using it. This further incorporates the intensity of belief as to what extent the technology will provide an advantage (Venkatesh \& Davis, 1996).

Most of the studies examining the acceptance or adoption of m-Learning utilizing different versions of TAM by Davis (1989) focused mostly on specific technological aspects. However, technological aspects alone would not provide the overall understanding about intention to adopt $\mathrm{m}$-Learning as adoption intention is multi-dimensional (Cheon et al., 2012). Along with technological aspects learner capabilities and motivation to use m-Learning will contribute towards a comprehensive understanding of the intention to use m-Learning. Therefore, in this study the TAM was extended incorporating system quality (IS success theory) (DeLone \& McLean, 2003), perceived self-efficacy (Self efficacy theory) (Bandura, 1994) and intrinsic motivation (Self-determination theory) (Deci \& Ryan, 2000) to provide a comprehensive multi-faceted view of m-Learning adoption intentions. The next section will discuss about the conceptual model and the hypotheses developed to answer the research question of this study.

\subsection{Research Model and Hypotheses}

The research model proposed in this study is an extension of the Technology Acceptance Model (TAM), integrating the mobile self-efficacy, system quality, intrinsic motivation, perceived ease of use, perceived usefulness and behavioral intention to use mobile devices for learning.

TAM theorises two important beliefs in relation to technology acceptance behaviour: (1) perceived usefulness and (2) perceived ease of use. Davis (1989, p.320) defined perceived usefulness (PU) as "the degree to which a person believes that using a particular system would enhance his or her job performance" and Perceived Ease of Use (PEOU) as "the degree to which a person believes that using a particular system would be free of effort". Thus, the actual system use heavily depends on these two factors. According to Davis, different external factors can be used to extend the TAM to better explain perceived ease of use and perceived usefulness and in turn the intention of behaviour. Extended versions of the TAM model have been empirically tested in different technological contexts since its inception (Surendran, 2012; Shafeek, 2011; Zhou, Dai \& Zhang, 2007; Pavlou, 2003; Legris, Ingham \& Collerette, 2003). Current study too, is using an extended version of the TAM model. The research model developed for this study is given in Figure 1. Based on the literature, the flow of causality of the research model was reflected by the connections among the constructs (see Figure 1). In this research model, system quality, mobile self-efficacy and intrinsic motivation, were hypothesised to affect perceived usefulness and perceived ease of use. 


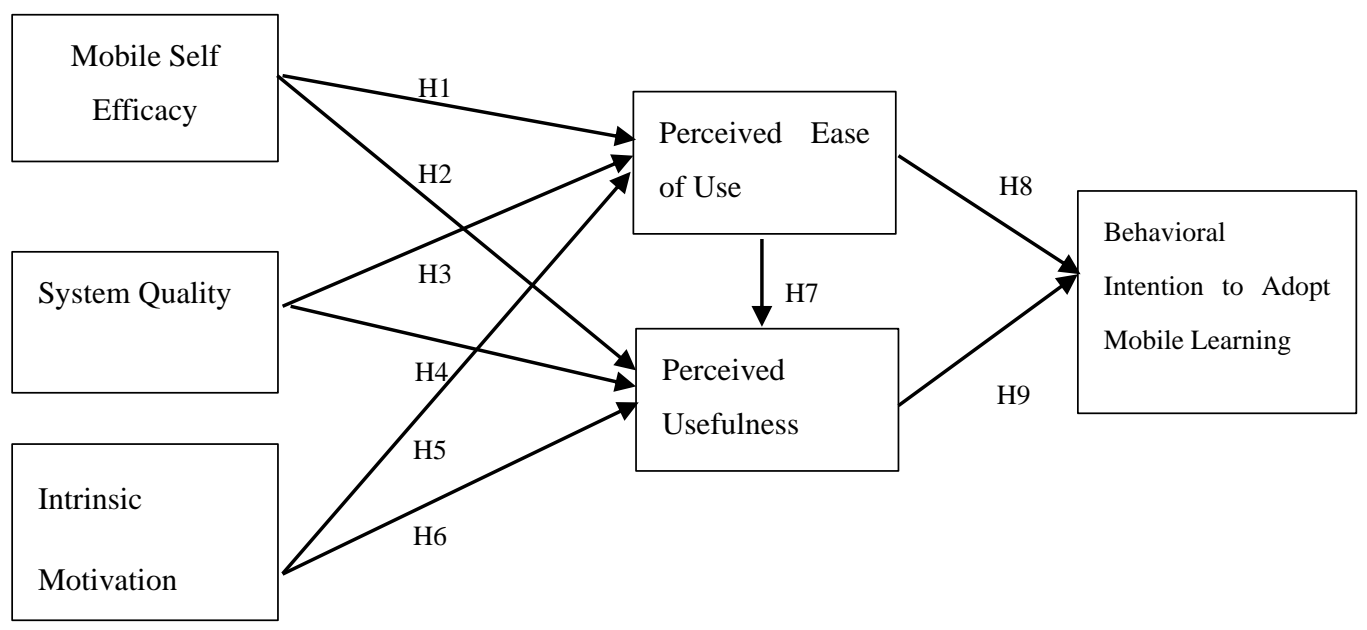

\subsubsection{Mobile Self-Efficacy}

Figure 1. Research Model

Self-efficacy is defined as people's beliefs about their capabilities to produce designated levels of performance that exercise influence over events that affect their lives. It decides how people feel, think, motivate themselves and behave (Bandura, 1994). Mobile self-efficacy considered in this research study is based upon the above mentioned general concept of self-efficacy (Bandura, 1982). Computer or web self-efficacy was studied by many scholars (Compeau \& Higgins, 1995; Lopez \& Manson, 1997). In order to ensure the success of the m-Learning process, it is necessary that a high level of confidence in using mobile technology as a part of their learning process is shown by the students (Mahat, Ayub \& Luan, 2012). According to the study on college students' acceptance of mobile learning conducted by Chung, Chen \& Kuo (2015), it was found that self-efficacy had a significant influence on perceived ease of use and perceived usefulness. Poong, Yamaguchi \& Takada (2017) in their study on drivers of mobile learning acceptance among young adults in Laos also found that self-efficacy had a significant influence on perceived ease of use and perceived usefulness. Based on that, mobile self-efficacy in this research study is hypothesized to have a direct impact on the perceived usefulness and the ease of use. Based on the above justification following hypotheses were formulated:

H1: Mobile self-efficacy has a positive effect on perceived usefulness of mobile learning.

H2: Mobile self-efficacy has a positive effect on perceived ease of use of mobile learning.

\subsubsection{System Quality}

System quality refers to the rating of the functions of a mobile learning system in terms of the information provided by the system and the efficacy of information transmission (Rui Hsin \& Lin 2017). Perceived system quality refers to the user's evaluation of the design and technical dimensions of an information system (Majed, 2013). Perceived system quality was studied by many researchers (Bailey \& Pearson, 1983; Belardo, Karwan, Wallace, \& Elling, 1984; Franz \& Robey, 1986; Seddon, 1997). However, depending on the intended technologies, the variables explaining system quality would differ (DeLone \& McLean, 2003).

Almasri (2016) in his study on the m-Learning environment in higher education in Jordan found that system quality has a significant positive impact on perceived usefulness and perceived ease of use. Khanh and Gim (2014) in their study on the factors affecting mobile learning adoption intention in higher education found that the quality of m-Learning systems had a positive impact on the perceived ease of use and perceived usefulness. Hence, system quality in this study is hypothesized to have a direct impact on the perceived usefulness and the ease of use. Based on the above justification following hypotheses were formulated:

H3: System Quality has a positive effect on perceived ease of use of mobile learning.

H4: System Quality has a positive effect on perceived usefulness of mobile learning.

\subsubsection{Intrinsic Motivation}

Intrinsic motivation refers to performing an activity because it is intrinsically enjoyable or challenging (Venkatesh, 1999; Hwang, Y. 2005; Lee, Jeon \& Kim, 2011; Wood, Larson \& Brown, 2009). Intrinsic motivation 
has been identified as a major factor in adopting a range of technologies within a wide extent of contexts (Davis, et al., 1992; Gefen, Straub \& Boudreau, 2000; Teo, Lim, \& Lai, 1999; Yi \& Hwang, 2003). IS research has also used motivation theories to investigate factors that influence the acceptance of technology, particularly focusing on intrinsic motivation (Iordache \& Lamanauskas 2010; Fagan, Neill \& Wooldridge, 2008). However, it was noted that researchers have raised the need for additional studies in explaining the role that intrinsic motivation plays in IT acceptance and use (Fagan et al., 2008). Conci, Pianesi and Zancanarao (2009) studied the intention to accept mobile phones among elderly population in Italy and found that intrinsic motivation significantly affect perceived ease of use and perceived usefulness. Fagan et al., (2008) found that intrinsic motivation as a determinant of perceived ease of use, in their study to identify the intention to use computers among first line managers in a mid-sized firm. Further, a study to examine the system experience of a selected group of undergraduates in a major university in the United States found that playfulness as an antecedent of perceived ease of use (Hackbarth, Grover \& Yi, 2003). Therefore, in this study, intrinsic motivation is hypothesized to have a direct impact on perceived usefulness and perceived ease of use. Based on the above justification following hypotheses were formulated:

H5: Intrinsic Motivation has a positive effect on perceived ease of use of mobile learning.

H6: Intrinsic Motivation has a positive effect on perceived usefulness of mobile learning.

\subsubsection{Perceived Ease of Use}

Perceived ease of use is defined as 'the degree to which a person believes that using a particular system would be free of physical and mental effort' (Davis 1989, p.320). In this study, perceived ease of use was referred to as how students experience less complex or less difficult situations in their academic use of the e-Learning system through their mobile device. Tselios, Daskalakis and Papadopoulou (2011) found that perceived ease of use positively influences the attitude to use an e-Learning system. Additionally, perceived ease of use was identified as the major factor determining the acceptance of e-Learning (Sivo, Gunter \& Cornell, 2005; Adwan, Adwan, \& Smedley, 2013). Ramayah, Siron, Dahlan \& Mohamad (2003) in their study on the technology usage among owners and managers of SME's found that perceived ease of use as a determinant of behavioral intention to use technology. Seyal, Noah, Rahman, Ramlie and Rahman (2015) in their study to examine students' attitude to $\mathrm{m}$-Learning found that there's a positive effect from the perceived ease of use on the students' intention to use mobile learning. Based on the above justification following hypotheses were formulated:

H7: Perceived ease of use has a positive effect on Perceived usefulness.

H8: Perceived ease of use has a positive effect on intention to adopt mobile learning.

\subsubsection{Perceived Usefulness}

According to Davis (1989) perceived usefulness refers to the degree to which a person believes that using a particular system would enhance his/her job performance (Davis 1989, 1993). In this study perceived usefulness was defined as the perception of the student that adapting mobile learning practices will accelerate their performance. A study conducted by Tselios et al. (2011) concluded that perceived usefulness as a major factor in determining the users' attitude towards using the system. A study conducted in Chilean academic contexts by Echeverri'a et al. (2011) revealed a positive relationship between perceived usefulness and the adoption of an instant messaging learning system that was institutionally supported. Tan, Ooi, Sim and Phusavat, (2012) found that, if individuals perceive that mobile applications will heighten the efficiency of their learning process, there is more likelihood to adapt mobile learning in their academic activities. Suki and Suki (2011) in their study on using mobile devices for learning revealed that there is a significant positive relationship between perceived usefulness and behavioral intention. Based on the above justification following hypothesis was formulated:

H9: Perceived usefulness has a positive effect on intention to adopt mobile learning.

\section{Method}

\subsection{Participants}

The participants in this study were 151 postgraduate students of a recognized state university in Sri Lanka. The study used convenience sampling to collect data (Creswell, 2013). They were enrolled for MBA and MSc programs in management. The study reported data from 151 participants, there were 55 males and 96 females, and their specializations varied. All the participants who responded had a smartphone (Sophisticated and advanced smart phones: $40 \%$ other types of smart phones: $60 \%$ ).

\subsection{Data Collection}

The survey instrument contained 27 items adapted from previous studies. The survey used a 7-point Likert scale 
to measure participants' perceptions, ranging from strongly disagree to strongly agree. The 7-point Likert scale is widely used for measuring attitudes in survey type research (Malhotra, 2010). Also, it has been widely used in IS and m-Learning studies (Alharbi \& Drew, 2014; Kljunić \& Vukovac, 2015). Thus, 7-point Likert scale was used in this study. There were two parts in the survey instrument. The first section was designed to collect participants' perception toward m-Learning. The remaining 06 questions were used to collect background information of survey participants. Researchers themselves administered the questionnaires. Two hundred questionnaires were distributed and out of this, hundred and fifty-one were usable for this study. The response rate was $92 \%$. The data were checked for their accuracy before the main data analysis.

\section{Results}

SmartPLS and Statistical Package for Social Sciences (SPSS version 23) were the software used for data analysis in this study. SPSS was used to describe the demographic characteristics of the sample. Partial Least Square (PLS) technique is commonly used in IS research (Haenlein \& Kaplan, 2004). Linear regression and covariance based Structural Equation Modeling (SEM) were the other alternative methods of data analysis used in IS research (Gefen et al., 2000). Linear regression was decided to be not appropriate in this study due to the complexity of the model used. Covariance-based techniques are most appropriate for well-established models (Goodhue, Lewis \& Thompson, 2006). Therefore, PLS was seen as the most appropriate method of analysis for new models (Hensler, Ringle, \& Rudolf, 2009; Goodhue, Lewis \& Thompson, 2006).

\subsection{Measurement Model Results}

SmartPLS was used to test the measurement model. Reliability and validity tests; factor loadings, internal consistency reliability, convergent validity and discriminant validity were used to establish the strength of the measurement model.

Item loadings, Composite reliability, Cronbach's Alpha and Average Variance Extracted (AVE) are given in Table 1. Item reliability refers to the extent to which the value of the estimate of the underlying construct provided by the measure is reflected by the item value (Gefen et al., 2000). Factor loadings of the items given in PLS usually explain item reliability. The threshold value considered for this study was 0.5 (Hair, Black, Babin \& Anderson, 2010). In order to ensure reliability, internal consistency reliability and factor loadings (item reliability) were examined. According to the results of the factor loadings (see Table 1), all the items were acceptable since they were above the threshold value. Cronbach alpha and composite reliability were used in SEM analysis to assess internal consistency reliability (Hair, Black, Babin \& Anderson, 2009). Coronbach alpha above 0.7 was taken as the threshold to establish the reliability of measurement items (Hair et al, 2009). All the Cronbach alpha values and composite reliability values were above the threshold (0.7), thus, reflecting a satisfactory level of reliability in measurement items.

Table 1. Internal consistency reliability and convergent validity of the measures

\begin{tabular}{lccc}
\hline Constructs & Composite reliability & Cronbach Alpha & AVE \\
\hline Mobile self-efficacy & 0.823 & 0.838 & 0.686 \\
Intrinsic motivation & 0.893 & 0.679 & 0.625 \\
System quality & 0.948 & 0.935 & 0.721 \\
Perceived ease of use & 0.969 & 0.957 & 0.887 \\
Perceived usefulness & 0.952 & 0.939 & 0.770 \\
Intention to adopt mobile learning & 0.974 & 0.96 & 0.925 \\
\hline
\end{tabular}

Nunnally (1978) mentioned that the purpose of validation is to give a higher level of confidence to the researchers, peers and the society regarding the positivist method selected to reveal the scientific truth. Hair et al. (2009) described validity as the degree to which a scale or the set of measures accurately represented the concept of interest. In order to establish construct validity of the measurement instrument, convergent and discriminant validity were used, as these are common elements in PLS - SEM providing evidence of construct validity (Hair et al., 2011, Wong, 2013). Hair et al. (2009) defined convergent validity as the extent to which two measures coming under the same concept are related. A high correlation indicates that the scale used is measuring the expected concept. Convergent validity was achieved via AVE (Hair et al., 2011). The AVE values for all the constructs considered (see Table 1) were above the threshold value of 0.5 (Bagozzi, Yi \& Phillips, 1991; Hair et al., 2011). Further, item reliability and internal consistency reliability can also be used to provide evidence for convergent validity. Hence, all these values supported in establishing convergent validity.

Hair et al. (2009) describes discriminant validity as the extent to which two conceptually similar concepts are distinct. Discriminant validity can be tested using the square root of AVE. Where, if these values are greater than the correlation among the other variables, it is said to fulfill discriminant validity. (Fornell \& Larcker, 1981). As given in Table 2, the square roots of AVE were observed to be higher than the correlation values. Hence, it could 
be concluded that the requirements of the discriminant validity were fulfilled.

Table 2. Discriminant validity results

\begin{tabular}{lcccccc}
\hline \multicolumn{1}{c}{ Constructs } & $\begin{array}{c}\text { Intention to } \\
\text { use mobile } \\
\text { learning }\end{array}$ & $\begin{array}{c}\text { Intrinsic } \\
\text { motivation }\end{array}$ & $\begin{array}{c}\text { Mobile Self } \\
\text { efficacy }\end{array}$ & $\begin{array}{c}\text { Perceived } \\
\text { ease of use }\end{array}$ & $\begin{array}{c}\text { Perceived } \\
\text { usefulness }\end{array}$ & $\begin{array}{c}\text { System } \\
\text { quality }\end{array}$ \\
\hline $\begin{array}{l}\text { Behavioral intention to adopt } \\
\text { mobile learning }\end{array}$ & $\mathbf{0 . 9 6 1 9}$ & & & & & \\
\hline Intrinsic motivation & 0.7519 & $\mathbf{0 . 7 9 0 4}$ & & & \\
Mobile Self efficacy & 0.7736 & 0.6968 & $\mathbf{0 . 8 2 8 0}$ & & \\
Perceived ease of use & 0.8308 & 0.7327 & 0.7716 & $\mathbf{0 . 9 4 1 6}$ & $\mathbf{0 . 8 7 7 5}$ \\
Perceived usefulness & 0.8414 & 0.7609 & 0.7673 & 0.8290 & 0.7840 & $\mathbf{0 . 8 4 9 4}$ \\
System quality & 0.7273 & 0.6581 & 0.6825 & 0.7315 & \\
\hline
\end{tabular}

The structural model needs to be tested following the validation of the measurement model, to verify the explanatory power of the model and to test the cause - effect relationships established between the constructs. The model's explanatory power was evaluated by examining the coefficient of determination $\left(\mathrm{R}^{2}\right)$. Hair et al. (2011) suggested that $R^{2}$ values $0.75,0.5$ and 0.25 of endogenous latent variables in the model can be respectively described as substantial, moderate or weak.

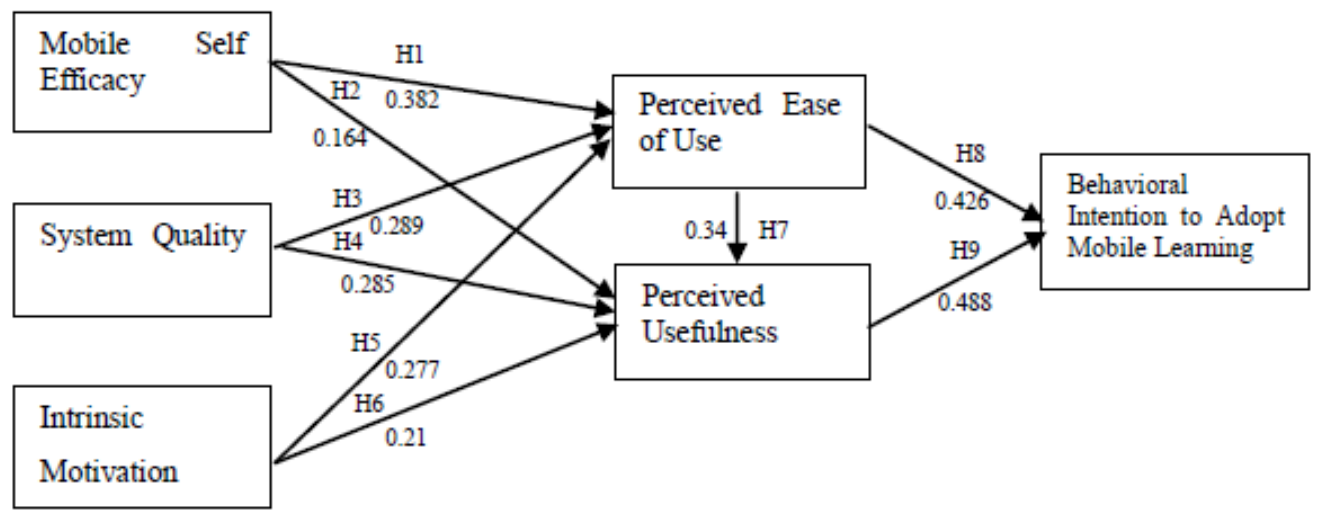

Figure 2. Structural Model Results

In order to test the explanatory power of the model and the hypotheses, the structural model was used. The coefficient of determination $\left(\mathrm{R}^{2)}\right.$ was used to assess the explanatory power of the model. The model explained $77 \%$ of variance in behavioral intention to adopt mobile learning, $71 \%$ in perceived ease of use and $79 \%$ in perceived usefulness (see Figure 2).

The strength of the relationships between the constructs was assessed using the path coefficient $(\beta)$ values. Further, the significance of the structural paths was tested using bootstrapping procedure (with 500 iterations) in PLS (Hair et al., 2011, Wong, 2013). Perceived usefulness had the strongest impact on the behavioral intention (0.488) followed by the perceived ease of use (0.426) (see Figure 2)

Thus, it could be concluded that all the hypothesized relationships constructed between the variables: mobile self efficacy and perceived ease of use $(\beta=0.382, p=0.0001)$; mobile self efficacy and perceived usefulness ( $\beta=$ $0.164, p=0.0048)$; service quality and perceived ease of use $(\beta=0.269, p=0.0003)$; service quality and perceived usefulness $(\beta=0.285, \mathrm{p}=0.0000)$; intrinsic motivation and perceived ease of use $(\beta=0.277, \mathrm{p}=$ $0.0005)$; intrinsic motivation and perceived usefulness $(\beta=0.21, \mathrm{p}=0.0018)$; perceived ease of use and perceived usefulness $(\beta=0.34, \mathrm{p}=0.0000)$; perceived ease of use and behavioral intention to adopt mobile technology for learning $(\beta=0.426, p=0.0000)$; perceived usefulness and behavioral intention to adopt mobile technology for learning $(\beta=0.488, \mathrm{p}=0.0000)$ were statistically significant.

\subsection{Hypotheses Testing}

As shown in Table 3, path coefficients $(\beta)$ which indicate the strength in the relationships between research constructs were used to test the hypotheses (Wang \& Chiu, 2011). Bootstrapping procedure in Smart PLS was used to test the significance of path coefficients $(\beta)$. Confidence level considered for testing the statistical significance was at $95 \%(\mathrm{p}<0.05)$. 
Table 3. Hypotheses testing results

\begin{tabular}{|c|c|c|c|}
\hline Hypotheses & $\begin{array}{c}\text { Path } \\
\text { Coefficient }(\beta)\end{array}$ & $P$ value & $\begin{array}{l}\text { Supported/ Not } \\
\text { supported }\end{array}$ \\
\hline H1: mobile self efficacy $\rightarrow$ perceived ease of use & 0.382 & 0.000 & Supported \\
\hline $\mathrm{H} 2:$ mobile self efficacy $\rightarrow$ perceived usefulness & 0.164 & 0.005 & Supported \\
\hline H3: system quality $\rightarrow$ perceived ease of use & 0.289 & 0.000 & Supported \\
\hline H4: system quality $\rightarrow$ perceived usefulness & 0.285 & 0.000 & Supported \\
\hline H5: intrinsic motivation $\rightarrow$ perceived ease of use & 0.277 & 0.001 & Supported \\
\hline H6: intrinsic motivation $\rightarrow$ perceived usefulness & 0.210 & 0.002 & Supported \\
\hline H7: perceived ease of use $\rightarrow$ perceived usefulness & 0.340 & 0.000 & Supported \\
\hline $\begin{array}{l}\text { H8: perceived ease of use } \rightarrow \text { behavioral intention to adopt mobile } \\
\text { technology for learning }\end{array}$ & 0.426 & 0.000 & Supported \\
\hline $\begin{array}{l}\text { H9: perceived usefulness } \rightarrow \text { behavioral intention to adopt mobile } \\
\text { learning }\end{array}$ & 0.488 & 0.000 & Supported \\
\hline
\end{tabular}

\section{Discussion}

This section presents the discussion of findings. The purpose of this study was to identify the factors affecting the intention to adopt m-Learning. According to the findings of this study, all the proposed hypotheses were supported, revealing that mobile learning adoption intention is multi-faceted. In this study, TAM was extended with three constructs, namely, mobile self-efficacy, system quality and intrinsic motivation. According to the findings there was a significant effect of perceived ease of use $(\beta=0.426 \mathrm{p}=0.000)$ and perceived usefulness $(\beta$ $=0.488 \mathrm{p}=0.000$ ) on intention to use showing that when students feel the system as easy and it is useful, it is more likely to use mobile learning among university students. This result is consistent with the findings of Suki and Suki (2011) and Tan et al. (2012) who found that there is a positive impact from perceived usefulness on the behavioral intention, and Seyal et al. (2015) who found that there's a positive effect from the perceived ease of use on the intention to use mobile learning. It was also found that there was a significant positive effect of perceived ease of use on perceived usefulness ( $B=0.340 \mathrm{p}=0.000$ ), meaning that when the students perceive $\mathrm{m}$-Learning to be easy to use, it will increase their feeling that the system is also useful for their study purposes. This finding is consistent with the finding of Hallegatte and Nantel (2006) who found that there was a significant positive impact of perceived ease of use on perceived usefulness. When considering the three external variables used in the model, mobile self efficacy (SE) significantly affected the perceived usefulness $(B=0.164 p=0.004)$ and perceived ease of use $(\beta=0.382 \mathrm{p}=0.000)$ of mobile learning. This means that when the students feel that they have some level of capability to achieve expected levels of outcomes using mobile technologies, it will enhance their feeling that the m-Learning system is useful for their learning and that it is easy to use. Therefore, $\mathrm{H} 1$ and $\mathrm{H} 2$ were supported. These findings are consistent with the findings of Chung et al. (2015) and Poong et al. (2017) who found that self efficacy had a significant positive influence on perceived ease of use and perceived usefulness. Further, system quality had a significant effect on perceived ease of use $(B=0.269 \mathrm{p}=$ $0.000)$ and perceived usefulness $(B=0.285 \mathrm{p}=0.000)$ of mobile learning, meaning when the information provided and the efficiency of the m-Learning system is high, it will enhance the students' feeling that m-Learning system is useful for their learning and that it is easy to use. Therefore, $\mathrm{H} 3$ and $\mathrm{H} 4$ were supported. These findings were consistent with Almasri (2016) and Khanh and Gim (2014) who found that system quality had a positive impact on perceived ease of use and perceived usefulness. According to the findings it was also observed that there was a significant impact of Intrinsic Motivation (IM) on perceived ease of use $(\beta=0.277 \mathrm{p}=$ $0.001)$ and perceived usefulness $(\beta=0.21 \mathrm{p}=0.001)$ of mobile learning showing that when the students find that using mobile technology for their learning is enjoyable it will enhance the students' feeling that $\mathrm{m}$-Learning is useful for their learning and that it is easy to use. Therefore, H5 and H6 were supported. These findings were consistent with the findings of Hackbarth, Grover and Yi (2003) and Fagan et al. (2008) who found that intrinsic motivation had a positive impact on perceived ease of use and perceived usefulness.

\section{Implications}

\subsection{Theoretical Implications}

This study was an extension of the TAM, incorporating three independent constructs namely: system quality, mobile self efficacy and intrinsic motivation from IS Success theory, Self efficacy theory and Self determination theory respectively. Hence, this study, contributed to fill the theoretical gap in the higher education context to a certain extent in relation to adopting mobile technology in teaching and learning.

\subsection{Managerial Implications}

The study focused on the factors affecting the adoption of mobile learning in higher education context and found 
that all factors were determinants of intention to use mobile technology in student learning. Thus, this finding would be very useful to the administrators of higher education institutions in introducing effective and efficient $\mathrm{m}$-Learning for students within their institutions. Since mobile self-efficacy was found to be the most significant independent variable affecting the perceived ease of use, this factor should be considered when developing learning management systems, by developing, promoting and encouraging mobile-enabled versions of learning management systems among students within the institutions. System quality was the second most significant factor which affected the perceived ease of use and usefulness of the systems. Thus, the developers of the $\mathrm{m}-$ Learning systems should focus on this aspect, by developing interfaces that are user friendly, easy to use, enabling flexible interaction, self - explanatory and easy to understand systems.

\section{Conclusion}

M-Learning adoption intention of students is a trending research topic since m-Learning applications are still in their early stages in the higher education context (Seyal et al., 2015). This study was an attempt to develop and validate a conceptual model based on a comprehensive review of literature. The model was an extension of the TAM (Davis, 1989). In this study, the TAM was extended with three constructs each from IS success theory, self-efficacy theory and self-determination theory. Among the independent variables considered for this study, it can be concluded that system quality has the highest impact on the students' intention to adopt m-Learning. That is, the rating of the mobile learning system's functions and the efficacy of its information transmission (Rui Hsin $\&$ Lin 2017), play a major role in their decision to adopt m-Learning.

Although this study did pave the way for many meaningful findings, it does have a few limitations as well. Firstly, the sample used in this study has covered only the MBA students. Therefore, future research is recommended to cover a more comprehensive student sample in different higher education contexts. Further, future research could identify other factors that would affect the intention to adopt mobile learning. As an implication, system developers and institutional administrators can concentrate more on factors such as mobile self - efficacy and system quality when developing Learning Systems within their institutions, since they significantly affected the perceived ease of use and perceived usefulness of mobile learning which in turn will affect the behavioral intention to adopt mobile technology for learning.

\section{References}

Abdullah, M. R. T. L., \& Siraj, S. (2010). M-Learning Curriculum Design for Secondary School: A Needs Analysis. International Journal of Social, Behavioral, Educational, Economic, Business and Industrial Engineering, 4(6), 1371-1376.

Adwan, A., Adwan, A., \& Smedley, J. (2013). Exploring students' acceptance of e-learning using Technology Acceptance Model in Jordanian universities. International Journal of Education and Development using Information and Communication Technology, 9(2), 4-18.

Aish, A., \& Love, S. (2013). Factors Influencing Students' Acceptance of M-Learning: An Investigation in Higher Education. The International Review of Research in Open and Distributed Learning, 14(5).

Ajzen, I. (1985). From intentions to action: A theory of planned behavior. In J. Kuhl \& J. Beckman (Eds.), Action control: From cognitions to behaviors (pp. 11-39). New York: Springer. https://doi.org/10.1007/978-3-642-69746-3_2

Ajzen, I. (1991). The theory of planned behavior. Organizational Behavior and Human Decision Processes, 50, 179-211. https://doi.org/10.1016/0749-5978(91)90020-T

Akour, H. (2009). Determinants of mobile learning acceptance: an empirical investigation in higher education (Doctoral Dissertation). Retrieved from ProQuest Dissertations \& Theses database.

Alharbi, S., \& Drew, S. (2014). Mobile Learning-system usage: Scale development and empirical tests. (IJARAI) International Journal of Advanced Research in Artificial Intelligence, 3(11), 31-35. https://doi.org/10.14569/IJARAI.2014.031105

Ally, M., \& Blázquez, P. (2014). What is the future of mobile learning in education? RUSC. Universities and Knowledge Society Journal, 1(11), 142-151. https://doi.org/10.7238/rusc.v11i1.2033

Almaiah, M. A., \& Jalil, M. A. (2014). Investigating Students' Perceptions on Mobile Learning Services. International Journal of Interactive Mobile Technologies, 8(4), 31-36. https://doi.org/10.3991/ijim.v8i4.3965

Almasri, F., \& Alshababi, D. B. (2016). New Mobile Learning Process Model for Higher Education Students in Jordanian Universities. Asian Journal of Information Technology, 15(12). 2016-2022. 
Al-Mushasha, F. N. (2010). Has the time for university's mobile learning come? Determining students' perception. Paper presented at The 12th International Conference on Information Integration and Webbased Application \& Services, Paris, France.

Andersson, A. (2008). Seven Major Challenges for E-Learning in Developing Countries Case Study eBIT, Sri Lanka, Informatics. International Journal of Education and Development using ICT, 4(3).

Bagozzi, R. P., Yi, Y., \& Phillips, L. W. (1991). "Assessing Construct Validity in Organizational Research," Administrative Science Quarterly, 36(3), 421-458. https://doi.org/10.2307/2393203

Bailey, J. E., \& Pearson, S. W., (1983). Development of a Tool for Measuring and Analyzing Computer User Satisfaction. Management Science, 29(5), 530-545. https://doi.org/10.1287/mnsc.29.5.530

Bandura, A. (1982). Self-efficacy mechanism in human agency. American Psychologist, 37(2), 122-147. https://doi.org/10.1037/0003-066X.37.2.122

Bandura, A. (1994). Self-efficacy. In V. S. Ramachaudran (Ed.), Encyclopedia of human behavior (Vol. 4, pp. 71-81). New York: Academic Press. (Reprinted in H. Friedman [Ed.], Encyclopedia of mental health. San Diego: Academic Press, 1998).

Baran, E. (2014). A review of research on mobile learning in teacher education. Educational Technology \& Society, 17(4), 17-32.

Belardo, S., Karwan, K., Wallace, W., \& Elling, R. (1984). "Managing the response to disasters using Microcomputers", Interfaces, 14(2), 29-39. https://doi.org/10.1287/inte.14.2.29

BenMoussa, C. (2003). Workers on the move: new opportunities through mobile commerce, Proceeding of the International Conference e- Society (IADIS), Lisbon, Portugal, 251-256.

Bogdanović, Z., Barać, D., Jovanić, B., Popović, S., \& Radenković, B. (2014). Evaluation of mobile assessment in a learning management system. British Journal of Educational Technology, 45(2), 231-244. https://doi.org/10.1111/bjet.12015

Calma, A., Webster, B., Petry, S., \& Pesina, J. (2014). Improving the quality of student experience in large lectures using quick polls. Australian Journal of Adult Learning, 54(1), 114-136.

Chen, G. D., Chang, C. K., \& Wang, C. Y. (2008). Ubiquitous learning website: Scaffold learners by mobile devices with information-aware techniques. Computers \& Education, 50(1), 77-90. https://doi.org/10.1016/j.compedu.2006.03.004

Cheon, J., Lee, S., Crooks, S. M., \& Song, J. (2012). An investigation of mobile learning readiness in higher education based on the theory of planned behavior. Computers and Education, 59(3), 1054-1064. https://doi.org/10.1016/j.compedu.2012.04.015

Chung, H. H., Chen, S. C., \& Kuo, M. H. (2015). A study of EFL college students' acceptance of mobile learning. Procedia-Social and Behavioral Sciences, 176, 333-339. https://doi.org/10.1016/j.sbspro.2015.01.479

Churchill, D., \& Churchill, N. (2008). Educational affordances of PDAs: A study of a teacher's exploration of this technology. Computes and Education, 50(4), 1439-1450. https://doi.org/10.1016/j.compedu.2007.01.002

Churchill, D., \& Wang, D. (2014). Teachers' use of I pads in higher education. Educational media international. 51(3), 214 -225. https://doi.org/10.1080/09523987.2014.968444

Compeau, D. R., \& Higgins, C. A. (1995). Computer self-efficacy: Development of a measure and initial test. MIS Quarterly, 19(2), 189-211. https://doi.org/10.2307/249688

Conci, M., \& Pianesi, F., \& Zancanaro, M. (2009). Useful, Social and Enjoyable: Mobile Phone Adoption by Older People. Human-Computer Interaction - INTERACT 2009. INTERACT 2009. Lecture Notes in Computer Science, 5726, 63-76. https://doi.org/10.1007/978-3-642-03655-2_7

Corbeil, J. R., \& Valdes-Corbeil, M. E. (2007). “Are you ready for mobile learning?” Educause Quarterly, 30(2), 51-58.

Costley, K. C. (2014). The positive effects of technology on teaching and student learning. Retrieved from http://files.eric.ed.gov/fulltext/ED554557.pdf

Crawford, V. M. (2007). Creating a powerful learning environment with networked mobile learning devices. Educational Technology Magazine: The Magazine for Managers of Change in Education, 47(3), 47-50. 
Creswell, J. W. (2013). Qualitative inquiry and research design: Choosing among five approaches (3rd ed.). Thousand Oaks, CA: Sage.

Davis, F. D. (1989). Perceived Usefulness, Perceived Ease of Use, and User Acceptance of Information Technology. MIS Quarterly, 13(3), 319-339. https://doi.org/10.2307/249008

Davis, F. D. (1993). User acceptance of information technology: system characteristics, user perceptions and behavioral impacts. Int. J. Man-Machine Stud., 38, 475-487. https://doi.org/10.1006/imms.1993.1022

Davis, F. D., Bagozzi, R. P., \& Warshaw, P. R. (1989). User acceptance of computer tech-nology: A comparison of two theoretical models. Management Science, 35(8), 982-1003. https://doi.org/10.1287/mnsc.35.8.982

Deci, E. L., \& Ryan, R. M. (2000).Self-determination theory and the facilitation of intrinsic motivation, social development, and well-being. American Psychologist, 55, 68-78. https://doi.org/10.1037/0003-066X.55.1.68

Delone, W. H., \& McLean, E. R. (2003). The DeLone and McLean model of Information Systems Success: A ten-year update. Journal of Management Information Systems, 19(4), 9-30. https://doi.org/10.1080/07421222.2003.11045748

Echeverrı'a, A., Nussbaum, M., Calderón, J., Claudio Bravo, C., Infante, C., \& Va'squez, A. (2011). Faceto-face collaborative learning supported by mobile phones. Interactive Learning Environments, 19(4), 351-363. https://doi.org/10.1080/10494820903232943

Engin, M., \& Donanci, S. (2015). Dialogic teaching and iPads in the EAP classroom. Computers \& Education, 88, 268-279. https://doi.org/10.1016/j.compedu.2015.06.005

Fagan, M., Neill, S., \& Wooldridge, B. (2008). Exploring the Intention to Use Computers: An Empirical Investigation of the Role of Intrinsic Motivation, Extrinsic Motivation, and Perceived Ease of Use. Journal of Computer Information Systems, 48(3), 31-37.

Fishbein, M., \& Ajzen, I. (1975). Belief, attitude, intention and behavior: An introduction to theory and research. Readring, MA: Addison-Wesley.

Fornell, C. G., \& Larcker, D. F. (1981). Evaluating structural equation models with unobservable variables and measurement error. Journal of Marketing Research, 18(1), 39-50. https://doi.org/10.1177/002224378101800104

Franz, C. R., \& Robey, D. (1986). Organizational Context, User Involvement, and the Usefulness of Information Systems. Decision Sciences, 17, 329-356. https://doi.org/10.1111/j.1540-5915.1986.tb00230.x

Gefen, D., Straub, D., \& Boudreau, M. (2000). Structural Equation Modeling Techniques and Regression: Guidelines for Research Practice. Communications of AIS (7:7 August,), pp 1 -78.

Gikas, J., \& Grant, M. (2013). Mobile Computing Devices in Higher Education: Student Perspectives on Learning with Cellphones, Smartphones \& Social Media. The Internet and Higher Education, 19, 18-26. https://doi.org/10.1016/j.iheduc.2013.06.002

Goodhue, D., Lewis, W., \& Thompson, R. (2006). PLS, Small Sample Size, and Statistical Power in MIS Research. in Proceedings of the 39th Annual Hawaii Conference on System Sciences, Los Alamitos, CA: IEEE Computer Society Press. https://doi.org/10.1109/HICSS.2006.381

Hackbarth, G., Grover, V., \& Yi, M. (2003). Computer playfulness and anxiety: positive and negative mediators of the system experience effect on perceived ease of use. Information \& Management. https://doi.org/10.1016/S0378-7206(02)00006-X

Haenlein, M., \& Kaplan, A. (2004). A Beginner's Guide to Partial Least Squares Analysis. Understanding Statistics, 3(4), 283-297. https://doi.org/10.1207/s15328031us0304_4

Hair, J. F., Black, W. C., Babin, B. J., \& Anderson, R. E. (2009). Multivariate data analysis. Upper Saddle River, NJ: Prentice Hall.

Hair, J. F., Ringle, C. M., \& Sarstedt, M. (2011). PLS-SEM: indeed a silver bullet. Journal of Marketing Theory and Practice, 19(2), 139-151. https://doi.org/10.2753/MTP1069-6679190202

Hair, J., Black, W. C., Babin, B. J., \& Anderson, R. E. (2010). Multivariate Data Analysis (7th Edition). NJ: Prentice-Hall Publication.

Hallegatte, D., \& Nantel, J. (2006). The Intertwined Effect of Perceived Usefulness, perceived ease of use and trust in a website on the intention to return. 
Hao, S., Mengyao, C., Dennen, V. P., Türel, Y. K., \& Li, M. (2017). Analysis of mobile learning as an innovation in higher education: a comparative study of three countries. International Journal of Mobile Learning and Organisation, 11(4), 314-339. https://doi.org/10.1504/IJMLO.2017.087080

Harris, P. (2001, July). Goin' mobile; learning circuits, Retrieved October 30, 2018, from http://www.learningcircuits.org

Henseler, J., Ringle, C. M., \& Rudolf, R. S. (2009). The use of partial least squares path modeling in international marketing, in Rudolf R. Sinkovics, Pervez N. Ghauri (ed.) New Challenges to International Marketing (Advances in International Marketing) Volume 20, Emerald Group Publishing Limited, 277-319.

Hwang, Y. (2005). Investigating enterprise systems adoption: uncertainty avoidance, intrinsic motivation, and the technology acceptance model. European Journal of Information Systems, 14(2), 150-161. https://doi.org/10.1057/palgrave.ejis.3000532

Iordache and Lamanauskas, (2014). Exploring the Usage of Social Networking Websites: Perceptions and Opinions of Romanian University Students. Informatica Economică, 17(4).

Keller, J. (2011). The slow motion mobile campus. The Chronicle of higher education.

Keskin, N. O., \& Metcalf, D. (2011). The Current Perspectives, Theories and Practices of Mobile Learning. The Turkish Online Journal of Educational Technology, 10, 202-208.

Khanh, N., \& Gim, G. (2014). Factors influencing mobile-learning adoption Intention: an empirical investigation in high Education. Journal of Social Sciences, 10(2), 51-62. https://doi.org/10.3844/jssp.2014.51.62

Klimova, B., \& Poulová, P. (2016). Mobile Learning in Higher Education. Advanced Science Letters, 22(5), 1111-1114. https://doi.org/10.1166/asl.2016.6673

Kljunić, J., \& Vukovac, D. (2015). A Survey on Usage of Mobile Devices for Learning among Tertiary Students in Croatia. Paper presented at the 26th Central European Conference on Information and Intelligent Systems.

Kuadey, N. (2010) Mobile Collaborative Learning System. Norwegian University of Science and Technology, Specialization Project Autumn.

Kukulska-Hulme (2007), Mobile Usability in Educational Contexts: What have we learnt?. International Review of Research in Open and Distance Learning, 8(2), 1-16. https://doi.org/10.19173/irrodl.v8i2.356

Lee, S. M., Jeon, S., \& Kim, S. T. (2011). Mobile Internet services: Assessment of quality and satisfaction from the customer's perspective. International Journal of Services Sciences, 4(1), 57-75. https://doi.org/10.1504/IJSSCI.2011.038460

Legris, P., Ingham, J., \& Collerette, P. (2003). Why do people use information technology? A critical review of the technology acceptance model. Information \& Management, 40, 191-204. https://doi.org/10.1016/S0378-7206(01)00143-4

Lillejord, S., Borte, K., Nesje, K., \& Ruud, E. (2018), Learning and teaching with technology in higher education. Knowledge centre for education, 1-64.

Lim, K. S., Lim, J. S., \& Heinrichs, J. H. (2005), Structural model comparison of the determining factors for e-purchase. Seoul Journal of Business, 11(2), 119-143.

Lim, T., Fadzil, M., \& Mansor, N. (2011). Mobile learning via SMS at Open University Malaysia: Equitable, effective and sustainable. The International Review of Research in Open and Distributed Learning, 12(2), 122-137. https://doi.org/10.19173/irrodl.v12i2.926

Liu, C., \& Arnett, K. P. (2000). Exploring the factors associated with website success in the context of electronic commerce. Information and Management, 38, 23-33. https://doi.org/10.1016/S0378-7206(00)00049-5

Liu, M., Scordino, R., Geurtz, R., Navarrete, C., Ko, Y., \& Lim, M. (2014). A look at research on mobile learning in K-12 education from 2007 to the present. Journal of Research on Technology in Education, 46(4), 325-372. https://doi.org/10.1080/15391523.2014.925681

Liu, Y., Li, H., \& Carlsson, C. (2010). Factors driving the adoption of m-learning: An empirical study. Computers and Education, 55, 1211-1219. https://doi.org/10.1016/j.compedu.2010.05.018

Lopez, D., \& Manson, D. (1997). A study of Individual Computer Self Efficacy and Percieved Usefulness of the Empowered Desktop Information System. Journal of Interdisciplinary Studies, 10, 83 
Lowenthal, J. (2010). Using Mobile Learning: Determinates Impacting Behavioral Intention. American Journal of Distance Education, 24(4), 195-206. https://doi.org/10.1080/08923647.2010.519947

Mahat, J., Ayub, A., \& Luan, W. (2012). Factors influence the acceptance of m-Learning in Malaysia: Perceived usefulness, perceived ease of use and attitude. Procedia - Social and Behavioral Sciences, 64, 284-290. https://doi.org/10.1016/j.sbspro.2012.11.033

Majed, A. (2013). The Impact of System Quality in E-learning System. Journal of Computer Science and Information Technology. 1(2).

Malhotra, N. K. (2010). Marketing Research. An Applied Orientation (6th edition). New Jersey: Pearson.

Nikkheslat, M., Zohoori, M., Bekheirnia, N., \& Mehrafshar, M. (2012). The important theories in term of applying green technologies and green processes in organizations: A study of Malaysian universities interdisciplinary. Interdisciplinary Journal of Contemporary Research in Business, 4(7), 88-102.

Nunnally, J. C. (1978). Psychometric theory (2nd ed.). New York: McGraw-Hill.

Nunnally, J. C., \& Bernstein, I. H. (1994) Psychometric theory (3rd ed.). New York, NY: McGraw-Hill, Inc.

O’Malley, C., Vavoula, G., Glew, J. P., Taylor, J., Sharples, M., Lefrere, L. N., \& Waycott, (2005). Guidelines for learning/teaching/tutoring in a mobile environment. Public deliverable from the MOBILearn project (D.4.1). hal-00696244.

Park, Y. (2011). A Pedagogical Framework for Mobile Learning: Categorizing Educational Applications of Mobile Technologies into Four Types. International Review of Research in Open and Distance Learning, 12(2), 79-102. https://doi.org/10.19173/irrodl.v12i2.791

Pavlou, P. A. (2003). "Consumer acceptance of electronic commerce: integrating trust and risk with the technology acceptance model". International Journal of Electronic Commerce, 7(3), 101-134. https://doi.org/10.1080/10864415.2003.11044275

Poong, Y. S., Yamaguchi, S., \& Takada, J. I. (2017). Investigating the drivers of mobile learning acceptance among young adults in the World Heritage town of Luang Prabang, Laos. Information Development, 33(1), 57-71. https://doi.org/10.1177/0266666916638136

Quinn, C. (2000). mLearning. Mobile, Wireless, In-Your-Pocket Learning. Linezine.

Ramayah, T., Siron, R., Dahlan, N., \& Mohamad, O. (2002). Technology Usage amongOwners/Managers Of SME's: The Role of Demographic and Motivational Variables, The proceedings of The 6th Annual Asian-Pacific Forum for Small Business on "Smalland Medium Enterprises Linkages, Networking and Clustering, Kuala Lumpur,Malaysia, 16-18th October 2002.

Redondo, E., Fonseca, D., Sánchez, A., \& Navarro, I. (2014). Mobile learning in the field of Architecture and Building Construction. A case study analysis. The International Journal of Educational Technology in Higher Education, 11(1), 152-174.

Reychav, I., \& Wu, D. (2015). Mobile collaborative learning: the role of individual learning in groups through text and video content delivery in tablets. Computer in Human Behavior, 50, 520-534. https://doi.org/10.1016/j.chb.2015.04.019

Reychav, I., Dunaway, M., \& Kobayashi, M. (2015). Understanding mobile technology-fit behaviors outside the classroom. Computers \& Education, 87, 142-150. https://doi.org/10.1016/j.compedu.2015.04.005

Rui Hsin, K., \& Lin, C. (2017). The usage intention of e-learning for police education and training. Policing: an international journal, 4l(1).

Seddon, P. B. (1997). A Respecification and Extension of the DeLone and McLean Model of IS Success. Journal of Information Systems Research, 8, 240-253. https://doi.org/10.1287/isre.8.3.240

Seyal A. H., Noah, Rahman, A., Ramlie, R., \& Rahman, A. A. (2015). A Preliminary Study of Students' Attitude on m-Learning: An Application of Technology Acceptance Model. International Journal of Information and Education Technology, 5(8). 609-614.

Shafeek, S. A. (2011). "E-learning technology acceptance model with cultural factors", MSc. Thesis, Liverpool John Moores University, School of Computing and Mathematical Sciences

Sharples, M. (2000). The design of personal mobile technologies for lifelong learning. Computers \& Education, 34, 177-193. https://doi.org/10.1016/S0360-1315(99)00044-5 
Sivo, S., Gunter, G., \& Cornell, R. (2005). Students' perceived ease of use of an elearning management system: an exogenous or endogenous variable? Educational Computing Research, 33(3), 285-307.

Suki, N. M., \& Suki, N. M. (2011). Using Mobile Device for Learning: From Students' Perspective. US-China Education Review A 1 p44-53.

Surendran, P. (2012). Technology Acceptance Model: A Survey of Literature. International Journal of Business and Social Research, 2(4).

Tan, G., Ooi, K., Sim, J., \& Phusavat, K. (2012). Determinants Of Mobile Learning Adoption: An Empirical Analysis. Journal of Computer Information Systems, 52.

Teo, T., Lim, V., \& Lai, R. (1999). Intrinsic and Extrinsic motivation in Internet Usage. Omega, 27, 25-37. https://doi.org/10.1016/S0305-0483(98)00028-0

Traxler, J. (2007). Defining, Discussing, and Evaluating Mobile Learning: The moving finger writes and having writ". International Review of Research in Open and Distance Learning, 8(2), 1-12. https://doi.org/10.19173/irrodl.v8i2.346

Traxler, J. (2010). Students and mobile devices. Research in Learning Technology, 18(2), 149-160. https://doi.org/10.1080/09687769.2010.492847

Tselios, N. K., Daskalakis, S., \& Papadopoulou, M. (2011). Assessing the acceptance of a blended learning university course. Educational Technology \& Society, 14(2), 224-235.

Venkatesh, V., \& Davis, F. D. (1996). A model of the antecedents of perceived ease of use: Development and test. Decision Sciences, 27(3), 451-481. https://doi.org/10.1111/j.1540-5915.1996.tb01822.x

Venkatesh, V., (1999). Creation of favorable user perceptions: Exploring the role of intrinsic motivation. MIS Quarterly, 23, 239-260. https://doi.org/10.2307/249753

Venkatesh, V., Morris, M. G., Davis, G. B., \& Davis, F. D. (2003). User acceptance of information technology: toward a unified view. MIS Quarterly, 27(3), 425-478. https://doi.org/10.2307/30036540

Wang, H. C., \& Chiu, Y. F. (2011). Assessing E-Learning 2.0 System Success. Computers \& Education, 57(2), 1790-1800. https://doi.org/10.1016/j.compedu.2011.03.009

Wang, M., Chen, Y., \& Khan, M. J. (2014). Mobile cloud learning for higher education: A case study of moodle in the cloud. The International Review of Research in Open and Distributed Learning, 15(2), 254-267. https://doi.org/10.19173/irrodl.v15i2.1676

Wang, Q., Zhu, Z., Chen, L., \& Yang, H. (2009). E-learning in China. Campus-Wide Information Systems, 26(2), 77-81. https://doi.org/10.1108/10650740910946783

Wang, Y., Wu, M., \& Wang, H. (2009). Investigating the determinants and age and gender differences in the acceptance of mobile learning. British Journal of Educational Technology, 40(1), 92-118. https://doi.org/10.1111/j.1467-8535.2007.00809.x

Wong, K. K. K. (2013). Partial Least Squares Structural Equation Modeling (PLS-SEM) Techniques Using SmartPLS, Marketing Bulletin, 24, 1-32.

Wood, D., Larson, R. W., \& Brown, J. (2009). How adolescents come to see themselves as more responsible through participation in youth programs. Child Development, 80, 295-309. https://doi.org/10.1111/j.1467-8624.2008.01260.x

Wood, K. (2003). Introduction to Mobile Learning (M Learning), FERL - Technology for E-Learning, BECTA ICT Research, March 2003.

Wu, J., \& Lu, X. (2013). Effects of Extrinsic and Intrinsic Motivators on Using Utilitarian, Hedonic, and Dual-Purposed Information Systems: A Meta-Analysis, Journal of the Association for Information Systems, 14(3), 153-191. https://doi.org/10.17705/1jais.00325

Wu, P., Hwang, G. J., Su, L., \& Huang, Y. (2012). A context-aware mobile learning system for supportive cognitive apprenticeships in nursing skills training. Educational Technology \& Society, 15(1), 223-236.

Yi, M. Y., \& Hwang, Y. (2003). Predicting the use of web-based information systems: self efficacy, enjoyment, learning goal orientation, and the technology acceptance model, International Journal on Human Computer Studies. https://doi.org/10.1016/S1071-5819(03)00114-9

Zampou, T., Saprikis, V., Markos, A., \& Vlachopoulou, M. (2012). Modelling users' acceptance of mobile 
services. Electronic Commerce Research, 12(2), 225-248. https://doi.org/10.1007/s10660-012-9092-x

Zhou, L., Dai, L., \& Zhang, D. (2007). Online shopping acceptance model-a critical survey of consumer factors in online shopping. J. Electr. Commerce Res., 8, 41-62.

\section{Copyrights}

Copyright for this article is retained by the author(s), with first publication rights granted to the journal.

This is an open-access article distributed under the terms and conditions of the Creative Commons Attribution license (http://creativecommons.org/licenses/by/4.0/). 